\title{
Evaluation of Carabid Beetle Diversity in Different Bioenergy Cropping Systems
}

\author{
Benjamin Mast ${ }^{1}$, Simone Graeff Hönninger ${ }^{1} \&$ Wilhelm Claupein ${ }^{1}$ \\ ${ }^{1}$ Institute of Crop Science, Universität Hohenheim, Fruwirthstrasse 23, 70599 Stuttgart, Germany \\ Correspondence: Benjamin Mast, Institute of Crop Science, Universität Hohenheim, Fruwirthstrasse 23, 70599 \\ Stuttgart, Germany. Tel: 49-711-4592-2380. E-mail: benjamin.mast@uni-hohenheim.de
}

Received: April 19, 2012 Accepted: May 23, 2012 Online Published: July 16, 2012

doi:10.5539/sar.v1n2p127

URL: http://dx.doi.org/10.5539/sar.v1n2p127

\begin{abstract}
Changes in agricultural land use as a consequence of an increased demand of energy crops have resulted in an increase of maize cropped area in many regions of Germany. The focus on maize as main biogas substrate, has led in some cases to negative ecological and environmental impacts, such as a loss of agro biodiversity reflected in a loss of field flora and fauna biodiversity. The present paper deals with the evaluation of the fauna in different bioenergy cropping systems on two sites in South-West Germany, with a special focus on the species richness of carabid beetle (Coleoptera: Carabidae) assemblages as an indicator for the general status of diversity. A maize field, an agroforestry system with maize and different tree species as well as different alternative biogas crops (amaranth, sunflower) was investigated for their carabid beetle activity, density, and species richness using pitfall traps. Moreover, for an adequate evaluation of the carabid assemblages different common diversity indices (Shannon-Wiener diversity $\left(H^{\prime}\right)$, Simpson diversity $(D)$ and Evenness $\left(J^{\prime}\right)$ ) were used. In the case of the maize field on both field edges 8 and 6 carabid beetle species, respectively were trapped, while in the field centre 2 carabid beetle species were trapped. The agroforestry system indicated slightly higher crabid beetle species richness close to the tree strips. The investigation of alternative biogas crops showed no significant differences in carabid beetle diversity. Overall, the results of the different studies showed, that biodiversity of bioenergy cropping systems could be enhanced by the creation of refuge areas for carabid beetles or other animals. Refuges could be either field margins with grass and hedgerows or strips of more extensively used perennial energy crops across the field.
\end{abstract}

Keywords: carabid beetle, biodiversity, bioenergy, cropping system

\section{Introduction}

Political targets on European and German level (Commission of the European Communities, 2005; BMU \& BMELV, 2010) considering the expansion of energy from biomass have resulted in a shift of agricultural area formerly used for food production now being used for energy production to satisfy the growing demand for energy crops. In conjunction with a still growing energy demand, the agricultural area which is used for the production of bioenergy crops increased intensively in Germany over the last years (FNR, 2012). Along with this, a concentration on a few important bioenergy crops (e.g. rapeseed for biodiesel, maize for biogas) could be observed, particularly with regard to biogas production in Germany. Maize is currently the main substrate for biogas production in Germany and in regions where a large number of biogas plants exists; a high maize density mainly cropped as maize monocultures often predominates. This focus on maize (or other crops cultivated in high densities or monocultures) as biogas substrate led in some cases to negative ecological and environmental impacts, such as increasing erosion, higher nitrogen loads in groundwater as well as a loss of agro biodiversity reflected in a loss of field flora and fauna biodiversity (SRU, 2007; Weidanz \& Mosimann, 2008; Vetter, 2010; Golebiowska, 2011). Furthermore, the general agricultural intensification led to a decline of biodiversity of agricultural landscapes caused by simplification of cropping systems, which resulted in reduced crop diversity and loss of non-crop habitats such as grassland and field boundaries (Stoate et al., 2001). These effects intensify with an expanding bioenergy production along with a strong focus on only a few important crops.

Particularly with regard to the flora and fauna biodiversity of bioenergy cropping systems, an investigation in Germany estimated a higher overall biodiversity of five organism groups (ground beetles, spiders, birds, flower visitors, weeds) in cropping systems with two or three crops when compared to monocultures (Vetter, 2010). In 
consequence of multifaceted habitat conditions more species find favourable habitat conditions and the species richness increases. Furthermore, maize is inherently a crop species with a low biodiversity (Vetter, 2010). This indicates a continuous loss of biodiversity in agricultural landscapes with a high density of monocultures in general and more specific with maize monocultures. Hence, in the course of an increasing bioenergy production a boarder diversification of the substrate supply using alternative crops and alternative cropping systems is needed to ensure an overall ecological and sustainable bioenergy production.

Carabid beetles are often used as an indicator for the fauna biodiversity of landscapes and agricultural ecosystems. Kromp (1999) describes carabid beetles as an important bioindicative value for cultivation impacts due to the sensitive reaction caused by anthropogenic changes as well as the well known ecology and the abundance in arable habitats all over the world.

Generally carabid beetles in the adult stage live on the soil surface; therefore they are also called ground beetles (Kromp, 1999). About 40000 carabid beetle species are known so far (Thiele, 1977) and in temperate zone one generation per year is produced (Kromp, 1999). Thiele (1977) distinguishes the carabid beetle species with regard to the habitat, into forest and field carabid beetles, whereas another distinction in 'autumn-breeders' and 'spring-breeders' may be carried out (Kromp, 1999 after Larsson, 1939). According to Allegro and Sciaky (2003) carabid beetles are considered as a bioindicator of ecosystem stability or stress. Furthermore, carabid beetles provide a benefit for the agricultural practise as a biological pest control agent (Kromp, 1999; Horne, 2007). Several agricultural activities like soil cultivation, plant protection and fertilization affect the carabid beetle assemblages and their species richness (Holland \& Luff, 2000). Similarly, field microclimate caused by the crop type, soil moisture and temperature influences also the carabid beetle composition (Thiele, 1977). The carabid beetle composition is also strongly influenced by the sowing time (winter or spring) of the corresponding crop (Holland \& Luff, 2000), for example root crops have extreme soil surface microclimates in early spring due to the bare soil, whereas the microclimate in winter crops at this time of the year is less extreme (Kromp, 1999). Concerning a possible effect of soil cultivation techniques on carabid assemblage the literature shows varying results, likely due to habitat conditions or preference of the carabid species. Baguette and Hance (1997) reported in their studies some carabid beetle species prefer ploughing as well as other carabid beetle species favouring reduced tillage, thus no effect of the tillage system was shown. An investigation in a cereal/pea crop rotation found a strong influence of the tillage regime on the carabid beetle species with a higher species richness and diversity in the no-till system (Hatten et al., 2007), whereas in a further study, the species richness was greater in the ploughed areas (Volkmar \& Kreuter, 2006). Ellsbury et al. (1998) compared a low chemical (fertilizer and pesticide) with a high chemical input system and found a greater abundance and diversity in the system with a low fertilizer and pesticide input. Further, a comparison of organic and conventional cultivated sites revealed greater carabid beetle species richness on the organic cultivated sites (Dritschilo \& Erwin, 1982).

In addition, several investigations have shown an important effect of the number of cultivated crops in a cropping system on the carabid beetle species richness and activity. In this context the number of carabid beetle species increased with the number of crops in the crop rotation. Willms et al. (2009) compared different crop rotations for bioenergy production with a maize monoculture and found $20-25 \%$ higher carabid beetle species richness in the crop rotations compared to maize monoculture. The higher carabid beetle diversity in the crop rotations originated out of a higher number of carabid beetles, which are specialized to the different crops of the crop rotation. In contrast the monoculture caused one-sided increments of the carabid beetle assemblages in this study (Willms et al., 2009). A comparison of a 4-yr (maize/soybean/triticale-alfalfa/alfalfa) with a 2-yr (maize/soy bean) crop rotation system regarding carabid beetles resulted in a higher species richness and activity density (O'Rourke et al., 2008). Further investigations with a cotton monoculture compared to a double cropping field (Liu et al., 2010) and a 4-yr crop rotation compared to a 2-yr crop rotation (Ellsbury et al., 1998) showed similar results.

Beside agricultural activities, the field size and the availability of non-crop habitats as adjacent field margins and hedgerows are considerable factors for the diversity of carabid beetles and the overall biodiversity in agricultural landscapes. The importance of these non-crop habitats as a refuge from adverse agricultural operations, overwintering sites and for breeding is evidently (Holland \& Luff, 2000). In the course of land consolidation, these habitats often disappeared and the field size increased due to the intensification of agriculture. Irmler (2003) reported a negative correlation between the field size and several carabid beetle species as well as an effect of length of the field margin on the species richness. Therefore, smaller fields often contain more carabid beetle species when compared to large fields (Irmler, 2003). Holland et al. (2005) suggested in the context of higher farmland diversity a reduction of the field size to achieve an improved boundary/field ratio. Furthermore, woody borders in the landscape also increase the overall diversity in agro-ecosystems (Holland \& Fahrig, 2000). But not 
only natural field margins are useful as habitats to enhance the species richness of carabid beetles in agricultural landscapes, also temporary sown refuge strips could be an efficient instrument offering a refuge for carabid beetles, finally increasing species richness, activity and density (Carmona \& Landis, 1999; Yu et al., 2006). Moreover, benefits for the general biodiversity of agricultural systems can be expected from the creation of refuge strips such as flowering strips (Jearnneret et al., 2003; Marshall et al., 2006) as well as hedges along the field (Pollard \& Holland, 2006). Thomas and Marshall (1999) found an increasing arthropod diversity in different habitats (crop, crop edge, more diverse sown plots and pre-existing hedgerow boundaries). The lowest diversity was found in the crop plots and the highest in the pre-existing hedgerow boundaries.

Against the background of an increasing demand of agricultural area for the production of energy crops and the general agricultural intensification, improved bioenergy cropping systems are needed. It is apparent that the carabid beetle diversity as well as the overall biodiversity of agricultural ecosystems could be enhanced by the previously mentioned measures such as crop rotation or the creation of refuge areas like hedge rows and field margins. The diversification of the crop rotation as well as the cropping system using alternative annual and perennial crops may a possible solution in this context.

In the course of a research project regarding the development of sustainable bioenergy production systems in Germany, an evaluation of the carabid beetle (Coleoptera: Carabidae) fauna of different bioenergy cropping systems (maize monoculture, agroforestry system and different alternative biogas crops) was carried out in the years 2010 and 2011 in Southern Germany. Here, the results of the evaluation are presented and discussed. The evaluation focused on the species richness of carabid beetles assemblages as an indicator for fauna biodiversity.

\section{Material and Methods}

\subsection{Site Conditions}

In 2010 and 2011 different cropping systems were assessed for their carabid beetle species richness on two sites in South-West Germany (Baden-Württemberg). The investigations were performed at the experimental station Ihinger Hof of the University of Hohenheim ( $478 \mathrm{~m}$ above sea level $\left.48^{\circ} 44^{\prime} \mathrm{N}, 8^{\circ} 56^{\prime} \mathrm{E}\right)$ and on a farmer's field near Rot bei Laupheim (528 m above sea level; $48^{\circ} 14^{\prime} \mathrm{N}, 9^{\circ} 56^{\prime} \mathrm{E}$ ). The long term average (40 years) air temperature and the total precipitation at the Ihinger Hof site are $8.3{ }^{\circ} \mathrm{C}$ and $691 \mathrm{~mm}$, respectively. In Rot bei Laupheim the long term average (30 years) air temperature and the total precipitation are $7.5^{\circ} \mathrm{C}$ and $750 \mathrm{~mm}$, respectively. Climate data are shown in Table 1. The major soil type of both sites was determined as Haplic Luvisol.

Table 1. Climate data (average temperature $\left({ }^{\circ} \mathrm{C}\right)$ and precipitation $(\mathrm{mm})$ ) of both experimental sites in 2010 and 2011

\begin{tabular}{rrcc}
\hline Site & Year & Average temperature $\left({ }^{\circ} \mathrm{C}\right)$ & Precipitation $(\mathrm{mm})$ \\
\hline Ihinger Hof & & 8.1 & 702 \\
& 2010 & 9.9 & 591 \\
2011 & & \\
\multicolumn{2}{l}{ Rot bei Laupheim } & 7.4 & 825 \\
2010 & 9.0 & 677 \\
2011 & & \\
\hline
\end{tabular}

\subsection{Field Experiments}

Three treatments were evaluated consisting of a maize monoculture, different alterantive biogas crops and an agroforestry system. Each treatment is briefly described below.

\subsubsection{Maize Field}

On the experimental site in Rot bei Laupheim a 5.6 hectare maize field was investigated for its species richness in the field centre and on both field edges in 2010. The field had a length of approximately $400 \mathrm{~m}$ and a width of approximately $140 \mathrm{~m}$. Maize was sown at the $23^{\text {rd }}$ April 2010 with a sowing density of 9 kernels $\mathrm{m}^{-2}$ and harvested at the $10^{\text {th }}$ October 2010. 


\subsubsection{Alternative Biogas Crops}

In 2011, a field experiment was established at the experimental site Ihinger Hof with different annual crops which are currently discussed as alternative crops for the production of biogas substrate and maize (Zea mays) as the most important biogas substrate for biogas. The annual crops used in this experiment were sunflower (Helianthus annuus), amaranth (Amaranthus) and a grass-legume mixture (red clover (Trifolium pratense) and perennial ryegrass (Lolium perenne)). The previous crop was winter barley (Hordeum vulgare) and oil radish (Raphanus sativus var. oleiformis) as a catch crop. The other management data are shown in Table 2. The experiment was set up as randomized block design with 3 replications in April and May 2011, with a plot size of $24 \mathrm{~m} \times 35 \mathrm{~m}$.

Table 2. Management data (sowing and harvest date, sowing density, nitrogen fertilization) of the annual crops at the Ihinger Hof trial site in 2011

\begin{tabular}{lllll}
\hline & Sowing date & Harvest date & Sowing density & $\begin{array}{l}\text { Nitrogen fertilization } \\
\left(\mathrm{kg} \mathrm{N} \mathrm{ha}^{-1}\right)\end{array}$ \\
\hline Maize & 26. April 2011 & 19. Sept. 2011 & $9.5-10$ kernels m & -2 \\
Sunflower & 19. April 2011 & 19. Sept. 2011 & 8 kernels m & 120 \\
Amaranth & 10. May 2011 & 19. Sept. 2011 & $135 \mathrm{kernels} \mathrm{m}^{-2}$ & 120 \\
Clover grass & 29. June 2011 & 8. Nov. 2011 & $42 \mathrm{~kg} \mathrm{ha}^{-1}$ & 80 \\
\hline
\end{tabular}

\subsubsection{Agroforestry System}

The carabid beetle species richness of an agroforestry system (Figure 1) was determined at the experimental site Ihinger Hof in 2010. The agroforestry system was established in 2007 and consisted of 3 maize strips (48 $\mathrm{m}$ width $\mathrm{x} 210$ length) separated by different $8 \mathrm{~m}$ wide $/ 210 \mathrm{~m}$ long wood strips. The wood strips consisted of (1) willow (Salix spp.) as short rotation coppice for energy production planted in 3 double rows with $0.75 \mathrm{~m}$ distance between the double rows, (2) walnut (Juglans regia) for high grade wood production planted in double rows with a distance of $4 \mathrm{~m}$ between the rows and $7.5 \mathrm{~m}$ within the row and (3) locally adapted hedge species (e.g. hornbeam (Carpinus betulus), elderberry (Sambucus nigra), bird cherry (Prunus avium), hawthorn (Crataegus monogyna)) with a planting density of $1.5 \mathrm{~m} \mathrm{x} 1.5 \mathrm{~m}$. Walnut and the locally adapted hedge species are undersown with grass. The wood strips have a length of $210 \mathrm{~m}$ and every wood strip consists of $75 \mathrm{~m}$ willow and walnut strips as well as $60 \mathrm{~m}$ locally adapted hedge strips (Figure 1). The willow strips were harvested the first time in February 2009 and in February 2012. The maize strips were sown on the $19^{\text {th }}$ April, 2010 and harvested on the $4^{\text {th }}$ October, 2010; the previous crop in 2009 was also maize.

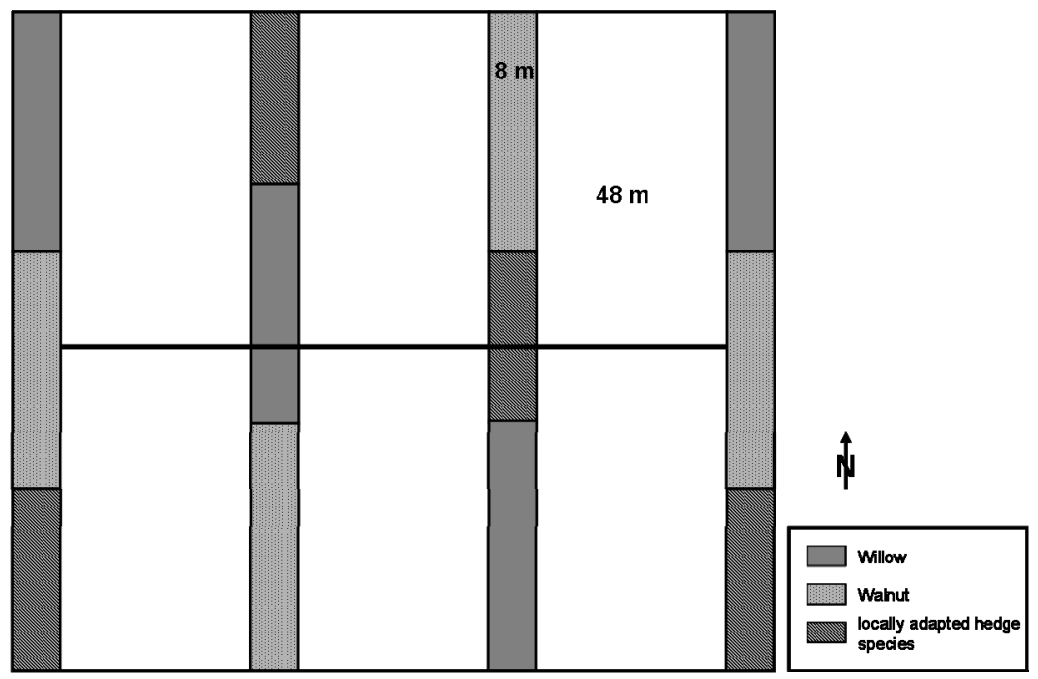

Figure 1. Design of the agroforestry system (3.7 ha) at the Ihinger Hof. The black line corresponds to the position of the transect for the sampling of carbide beetles. 


\subsection{Carabid Beetle Sampling}

Carabid beetle species richness was monitored using pitfall traps, which were 0.41 plastic cups (diameter: 85 $\mathrm{mm}$ and height: $130 \mathrm{~mm}$ ), buried flush to the soil surface containing a mixture of ethylene glycol and distillate water in a ratio 1:1. Plastic rooftops were used as rain protection. In the agroforestry system at the Ihinger Hof, the pitfall traps were arranged along a transect $(160 \mathrm{~m})$ including 15 pitfall traps crosswise to the maize and wood strips (Figure 1). Each maize strip included 5 pitfall traps with a distance of $16 \mathrm{~m}$ between each trap, whereas on both edges of the maize strips a pitfall trap was installed close to the wood strips. The pitfall traps were used for a period of 14 days in the field between $4^{\text {th }}$ and $21^{\text {st }}$ June 2010.

Regarding the field experiment with the annual crops in 2011, two pitfall traps per plot were used for two periods of 14 days $\left(14^{\text {th }}-27^{\text {th }}\right.$ June 2011 and $23^{\text {rd }}$ August $-6^{\text {th }}$ September 2011). At the experimental site in Rot bei Laupheim, 3 transects one in the centre of the field and one on every edge with a distance of $5 \mathrm{~m}$ to the field margin were established in the maize field during a 14 days period $\left(7^{\text {th }}-22^{\text {nd }}\right.$ June 2010$)$. Pitfall traps were installed with a distance of $10 \mathrm{~m}$ in the soil within the transect.

\subsection{Data and Statistical Analysis}

In addition to the activity density (number of carabid beetle individuals $(n)$ ) and the species richness (number of carabid beetle species) of the carabid beetle assemblages for each cropping system and experimental site, 3 common biodiversity indices were calculated:

\section{Shannon-Wiener-Index}

$$
H^{\prime}=-\sum_{i=1}^{S} p_{i} \ln p_{i}
$$

where $S$ is the total number of species and $p_{i}$ is the proportion of the $i$ th species. The species diversity measured by the Shannon-Wiener-Index increase with more equitable distribution among the species (Krebs, 2009).

\section{Simpson-Index}

$$
D=1-\sum^{S} p_{i}^{2}
$$

where $S$ is the total number of species and $p_{i}$ is the proportion of the $i$ th species. Essentially, the Simpson-Index captures the variance of the species abundance distribution, the diversity increase when $D$ (expressed as $1-D$ ) increase (Magurran, 2004).

\section{Evenness}

$$
J^{\prime}=H^{\prime} / H_{\max }
$$

where $H^{\prime}$ is the diversity value, in this case from the Shannon-Wiener function and $H_{\max }$ is the maximum diversity $\left(H_{\max }=\ln S\right)$. The Evenness measure ranges between 0 and 1 and captures the ratio of observed diversity to maximum diversity, which is existent in a situation where all species had equal abundances (Magurran, 2004). If $J$ ' approaching 1 the assemblage composition is almost equally distributed and balanced, whereas when $J$ ' tending towards 0 , the assemblage composition shows an unbalanced distribution (Allegro \& Sciaky, 2003).

For statistical analysis of the acquired data, an ANOVA (analysis of variance) was carried out using SigmaStat 3.5 (Systat Software Inc., 2005). The differences of the mean values were calculated using a Tukey-Test at the $5 \%$ level of probability. To create graphs SigmaPlot (Systat Software Inc., 2006) was used.

\section{Results and Discussion}

\subsection{Maize Field (Treatment 1)}

The species collected at the maize field in Rot bei Laupheim (all three transects) as well as their absolute and relative abundance are shown in Table 3. The highest number of individuals was collected from the carabid beetle species Pterostichus melanarius with 114 individuals and a relative abundance of $73.5 \%$ of the total number of carabid beetles found at this experimental site. 
Table 3. Number of carabid beetle individuals collected at the maize field in Rot bei Laupheim, sampling period $7^{\text {th }}-22^{\text {nd }}$ June 2010 and their relative abundance (\%)

\begin{tabular}{lcc}
\hline Species & Number of individuals $(n)$ & Frequency $(\%)$ \\
\hline Pterostichus melanarius (ILLIGER) & 114 & 73.5 \\
Carabus cancellatus (ILLIGER) & 18 & 11.6 \\
Poecilus cupreus (LINNÉ) & 6 & 3.9 \\
Agonum muellerie (HERBST) & 5 & 3.2 \\
Carabus auratus (LINNÉ) & 5 & 3.2 \\
Carabus granulatus (LINNÉ) & 2 & 1.3 \\
Pterostichus vernalis (PANZER) & 2 & 1.3 \\
Harpalus affinis (SCHRANK) & 1 & 0.7 \\
Amara aenea (DE GEER) & 1 & 0.7 \\
Calathus erratus (C.R. SAHLBERG) & 1 & 0.7 \\
Total & 155 & \\
\hline
\end{tabular}

The carabid beetle sampling at the maize field in Rot bei Laupheim in 2010 showed clear differences in carabid beetle species richness between the field centre and the field borders on both boundaries. On the left field border eight and on the right field border six different carabid species were trapped, whereas in the field centre only two different carabid species were trapped (Figure 2). Thus, higher carabid beetle species richness at both field edges of the maize field was obvious. The calculation of the diversity indices (Shannon-Wiener $\left(H^{\prime}\right)$, Simpson $(D)$ and Evenness $\left(J^{\prime}\right)$ ) for this experimental site (Table 4) showed similar results as for the species richness. Low diversity values were observed for the field centre $\left(H^{\prime}=0.146 ; D=0.064 ; J^{\prime}=0.211\right)$ whereas higher diversity values were observed for both field edges. The left field edge $\left(H^{\prime}=1.517 ; D=0.669 ; J^{\prime}=0.73\right)$ represented much higher diversity values when compared to the diversity values at the right field edge $\left(H^{\prime}=0.61 ; D=0.258\right.$; $\left.J^{\prime}=0.341\right)$. This is due to the fact that at the right field edge Pterostichus melanarius was the dominating species with $86 \%$ individuals of the total number of individuals from all six species. This indicates an unbalanced distribution of the carabid beetle assemblage on the right field edge when compared to the left field edge, but still higher species richness when compared to the field centre of the investigated maize field.

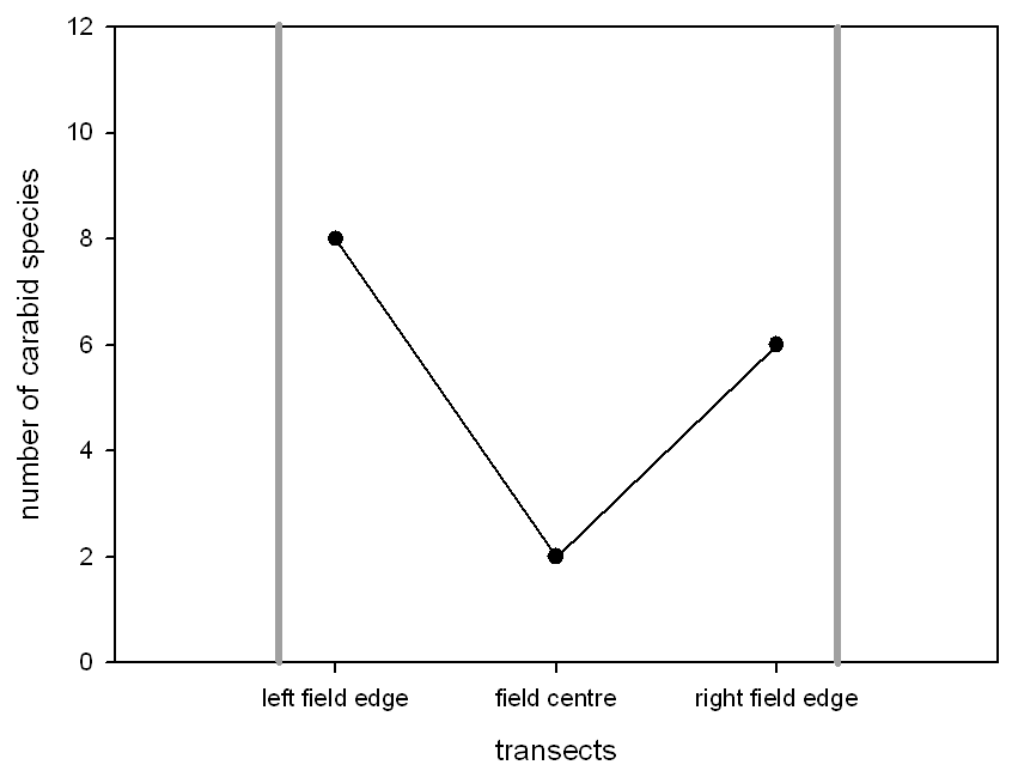

Figure 2. Carabid beetle species richness at the maize field in Rot bei Laupheim, sampling period $7^{\text {th }}-22^{\text {nd }}$ June 2010. Grey strips = field borders. Distance from the left field edge to the right field edge $140 \mathrm{~m}$, from the field 
edges to the middle $70 \mathrm{~m}$ and field length $400 \mathrm{~m}$.

Table 4. Activity density, species richness, Shannon-Wiener diversity $\left(H^{\prime}\right)$, Simpson diversity $(D)$ and Evenness $\left(J^{\prime}\right)$ for the three transects on the left field edge, the field centre and the right field edge at the maize field in Rot bei Laupheim, sampling period $7^{\text {th }}-22^{\text {nd }}$ June 2010. Distance from the left field edge to the right field edge 140 $\mathrm{m}$, from the field edges to the middle $70 \mathrm{~m}$ and total field length $400 \mathrm{~m}$.

\begin{tabular}{llllll}
\hline & $\begin{array}{l}\text { Activity } \\
\text { density }\end{array}$ & Species richness & $\begin{array}{l}\text { Shannon } \\
\text { diversity }\left(H^{\prime}\right)\end{array}$ & $\begin{array}{l}\text { Simpson } \\
\text { diversity }(D)\end{array}$ & Evenness $\left(J^{\prime}\right)$ \\
\hline Left field edge & 26 & 8 & 1.517 & 0.669 & 0.73 \\
Field centre & 30 & 2 & 0.146 & 0.064 & 0.211 \\
Right field edge & 99 & 6 & 0.61 & 0.258 & 0.341 \\
\hline
\end{tabular}

Both field borders were flanked by a few meter grass strips as non-crop habitats between the next fields indicating that field margins may enhance the carabid species richness in agricultural areas as shown in literature. Field margins have a great importance as non-crop habitat for carabid beetles as well as other arthropods for overwintering, summer recruitment as well as for providing a refuge from adverse agricultural activities (Sotherton, 1984; Holland \& Luff, 2000; Holland et al., 2005; Benjamin et al., 2008). Thus, several species are able to move from field margins into the agricultural field (Kromp \& Steinberger, 1992) at a later point. However, Saska et al. (2007) determined different ecological groups of carbide beetles (boundary species, field-interior species and field edge species) depending on their favourite habitat. The investigated maize field had a size of 5.6 hectare and a width of $140 \mathrm{~m}$. In this investigation, the carabid beetle species richness was higher at both field borders $5 \mathrm{~m}$ beside the grassy field margins than in the middle of the field about $70 \mathrm{~m}$ from both field margins. In a study regarding the spatial distribution of carabid beetles, Holland et al. (1999) found carabid beetles only $60 \mathrm{~m}$ from the field border. Furthermore, the boundary/field ratio and thus the field size also have a strong impact on carabid beetle and overall diversity of agricultural areas (Irmler, 2003; Holland et al., 2005). Irmler (2003) showed a negative correlation between field size and carabid beetle species richness with higher species richness in smaller fields, which is also resembled by the low values of Shannon-Wiener Index and Simpson diversity as well as the Evenness for the field centre of the investigated maize field. In addition, maize is in any case a crop with a low biodiversity, particularly if it is cropped as monoculture (Vetter, 2010). Appropriate solutions to reach a higher diversity in maize cropping systems may be the creation of refuge strips. Several investigations showed improvements regarding carabid beetle diversity (Carmona \& Landis, 1999, Yu et al., 2006) and overall biodiversity (Jeanneret et al., 2003; Marshall et al., 2006) with the establishment of grass or flowering strips. In addition, woody field strips and hedgerows are considered to promote the biodiversity of agricultural ecosystems exceedingly (Thomas \& Marshall, 1999; Holland \& Fahrig, 2000; Pollard \& Holland, 2006).

\subsection{Alternative Biogas Crops (Treatment 2)}

Moreover, crop rotations are able to improve the biodiversity of agricultural ecosystems when compared to monocultures. Several studies found increased carabid beetle species richness (Ellsbury et al., 1998; O'Rourke et al., 2008; Liu et al., 2010) as well as increased overall biodiversity (Willms et al., 2009) in crop rotation systems. Therefore, associated with a sustainable biogas production in Germany crop rotations for the production of biogas crops are currently discussed to achieve improvements compared to maize monocultures on biodiversity and overall environmental level. Carabid beetle species were trapped in a field experiment with different eligible alternative crops for biogas production in order to give evidence about the habitat conditions and overall biodiversity of these different crops. Two sampling periods were used in 2011. The individual species and the dominate structure found during this two sampling periods are shown in Table 5 (June) and Table 6 (August). Within the sampling period in June, Pterostichus melanarius was identified as the dominating species with a proportion of $77.1 \%$ of the total individual number. The sampling period in August presented a more balanced individual distribution and a lower number of total individuals compared with the first sampling period. Species with the highest proportion of individuals were Pseudoophonus rufipes with $28 \%$. 
Table 5. Number of carabid beetle individuals collected in the plots of amaranth, sunflower and maize at the experimental site Ihinger Hof, $14^{\text {th }}-27^{\text {th }}$ June 2011 and their relative abundance (\%)

\begin{tabular}{lcc}
\hline Species & Number of individuals $(n)$ & Frequency $(\%)$ \\
\hline Pterostichus melanarius (ILLIGER) & 729 & 77.1 \\
Pterostichus anthracinus (ILLIGER) & 116 & 12.3 \\
Anchomenus dorsalis (PONTOPPIDAN) & 32 & 3.4 \\
Carabus monilis (FABRICIUS) & 15 & 1.6 \\
Agonum muellerie (HERBST) & 8 & 0.8 \\
Poecilus cupreus (LINNÉ) & 7 & 0.7 \\
Pseudoophonus rufipes (DE GEER) & 6 & 0.6 \\
Bembidion obtusum (AUDINET-SERVILLE) & 6 & 0.6 \\
Bembidion guttula (FABRICIUS) & 6 & 0.6 \\
Pterostichus oblongopunctatus (FABRICIUS) & 4 & 0.4 \\
Carabus violaceus (LINNÉ) & 3 & 0.3 \\
Bembidion quadrimaculatum (LINNÉ) & 2 & 0.2 \\
Abax prarallelepipedus (PILLER \& MITTERPACHER) & 2 & 0.2 \\
Badister sodalis (DUFTSCHMID) & 1 & 0.1 \\
Abax parallelus (DUFTSCHMID) & 1 & 0.1 \\
Bembidion lampros (HERBST) & 1 & 0.1 \\
Clivina fossor (LINNÉ) & 1 & 0.1 \\
Carabus auronitens (FABRICIUS) & 1 & 0.1 \\
Carabus arvensis (HERBST) & 1 & 0.1 \\
Oodes helopioides (FABRICIUS) & 1 & 0.1 \\
Carabus granulatus (LINNÉ) & 1 & 0.1 \\
Amara ovata (FABRICIUS) & 1 & 0.1 \\
Amara lucida (DUFTSCHMID) & 946 & 0.1 \\
Total & & \\
\hline
\end{tabular}

Table 6. Number of carabid beetle individuals collected in the plots of amaranth, sunflower, maize and grass-legume mixture at the experimental site Ihinger Hof, $23^{\text {rd }}$ August $-6^{\text {th }}$ September 2011 and their relative abundance (\%).

\begin{tabular}{llc}
\hline Species & Number of individuals $(n)$ & Frequency (\%) \\
\hline Pseudoophonus rufipes (DE GEER) & 67 & 28.0 \\
Pterostichus anthracinus (ILLIGER) & 30 & 12.5 \\
Pterostichus melanarius (ILLIGER) & 28 & 11.7 \\
Carabus monilis (FABRICIUS) & 23 & 9.6 \\
Poecilus cupreus (LINNÉ) & 22 & 9.2 \\
Calathus erratus (C.R. SAHLBERG) & 10 & 4.2 \\
Ophonus ardosiacus (LUTSHNIK) & 9 & 3.8 \\
Anchomenus dorsalis (PONTOPPIDAN) & 8 & 3.4 \\
Loricera pilicornis (FABRICIUS) & 7 & 2.9 \\
Carabus granulatus (LINNÉ) & 6 & 2.5 \\
\hline
\end{tabular}




\begin{tabular}{lll}
\hline Carabus cancellatus (ILLIGER) & 6 & 2.5 \\
Bembidion decorum (PANZER) & 6 & 2.5 \\
Carabus violaceus (LINNÉ) & 3 & 1.3 \\
Agonum muellerie (HERBST) & 3 & 1.3 \\
Carabus auratus (LINNÉ) & 2 & 0.8 \\
Calathus cinctus (MOTSCHULSKY) & 2 & 0.8 \\
Bembidion testaceum (DUFTSCHMID) & 2 & 0.8 \\
Notiophilus palustris (DUFTSCHMID) & 1 & 0.4 \\
Amara communis (PANZER) & 1 & 0.4 \\
Bembidion quadrimaculatum (LINNÉ) & 1 & 0.4 \\
Abax parallelus (DUFTSCHMID) & 1 & 0.4 \\
Harpalus affinis (SCHRANK) & 1 & 0.4 \\
Total & 239 & \\
\hline
\end{tabular}

Table 7. Activity density, species richness, Shannon diversity $\left(H^{\prime}\right)$, Simpson diversity $(D)$ and Evenness $\left(J^{\prime}\right)$ for amaranth, sunflower, maize and grass-legume-mixture at the experimental site Ihinger Hof, sampling periods $14^{\text {th }}-27^{\text {th }}$ June 2011 and $23^{\text {rd }}$ August- $6^{\text {th }}$ September 2011

\begin{tabular}{clllll}
\hline & Activity density & Species richness & $\begin{array}{l}\text { Shannon } \\
\text { diversity }\left(H^{\prime}\right)\end{array}$ & $\begin{array}{l}\text { Simpson } \\
\text { diversity }(D)\end{array}$ & Evenness $\left(J^{\prime}\right)$ \\
\hline June & & & & & \\
Amaranth & $119.0 \pm 31.61 \mathrm{a}$ & $5.5 \pm 1.57 \mathrm{a}$ & 1.047 & 0.412 & 0.378 \\
$\begin{array}{c}\text { Sunflower } \\
\text { Maize }\end{array}$ & $100.0 \pm 31.22 \mathrm{a}$ & $4.67 \pm 1.09 \mathrm{a}$ & 0.929 & 0.412 & 0.362 \\
$\begin{array}{c}\text { August } \\
\text { Amaranth }\end{array}$ & $27.3 \pm 42 \mathrm{a}$ & $4.33 \pm 1.02 \mathrm{a}$ & 0.802 & 0.359 & 0.348 \\
$\begin{array}{c}\text { Sunflower } \\
\text { Maize }\end{array}$ & $20.6 \pm 10.41 \mathrm{a}$ & $4.0 \pm 0.86 \mathrm{a}$ & 2.216 & 0.82 & 0.768 \\
$\begin{array}{c}\text { Grass-legume } \\
\text { mixture }\end{array}$ & $12.6 \pm 3.79 \mathrm{a}$ & $3.5 \pm 0.56 \mathrm{a}$ & 1.952 & 0.824 & 0.783 \\
\hline
\end{tabular}

The results of the species richness capture are shown in Table 7. Both sampling periods revealed small but no significant differences in carabid beetle species richness between amaranth, sunflower and maize (June) and amaranth, sunflower, maize and grass-legume mixture (August), respectively. Amaranth showed in both sampling periods the highest average carabid beetle species richness with 5.5 carabid species, whereas in sunflower 4.7 (June) and 4 (August), respectively, carabid beetle species were found. Maize had with 4.3 (June) and 3.5 (August) in both sampling periods the lowest carabid beetle species richness. The grass-legume mixture plots were only trapped in August 2011 due to the late sowing date. The determined average carabid beetle species richness in the grass-legume mixture was 4.3.

Furthermore, diversity indices were calculated from the collected carabid beetle species and individuals (Table 7). Generally, the diversity values calculated for the second sampling period in August were higher compared to the diversity values from the first sampling period in June due to more balanced carabid beetle assemblage distribution at the second sampling period. The carabid beetle sampling at the first sampling period indicated Pterostichus melanarius as the dominating species with proportions between 75 and $79 \%$ depending on the crop. Within the first sampling period the differences of the diversity values between amaranth $\left(H^{\prime}=1.047 ; D=0.412\right.$; $\left.J^{\prime}=0.378\right)$, sunflower $\left(H^{\prime}=0.929 ; D=0.412 ; J^{\prime}=0.362\right)$ and maize $\left(H^{\prime}=0.802 ; D=0.359 ; J^{\prime}=0.348\right)$ plots were low. The second sampling period showed similar characteristics regarding the differences between the 
diversity values between the plots of amaranth $\left(H^{\prime}=2.028 ; D=0.797 ; J^{\prime}=0.768\right)$, sunflower $\left(H^{\prime}=2.216 ; D=\right.$ $\left.0.82 ; J^{\prime}=0.783\right)$, maize $\left(H^{\prime}=1.952 ; D=0.824 ; J^{\prime}=0.848\right)$, and grass-legume mixture $\left(H^{\prime}=2.102 ; D=0.844\right.$; $J^{\prime}=0.819$ ).

The results indicate that a certain adaptation time in crop rotations may be needed to establish a new species balance in the ecosystem. Maize showed the lowest carabid beetle species richness as well as the lowest Shannon-Wiener diversity when compared to the other crops, indicating that, if maize is cropped as monoculture over years the carabid beetle species richness may decrease. In general, monocultures have a cumulative effect on one-side increments regarding to the flora and fauna abundance, whereas the crop change within a crop rotation may have a balancing effect on biodiversity (Willms et al., 2009). The next experimental years will show the further development of carabid beetle species richness in such a system.

Furthermore, the integration of a grass-legume mixture or other perennial crops into the crop rotation may provide suitable refuges and increase the fauna diversity which will be reflected by Shannon-Wiener and Simpson diversity as well as Evenness showing high diversity values. In this context O'Rourke et al. (2008) found advantages for carabid beetle diversity in perennial crops such as alfalfa or crops with an early canopy formation. With this it seems to be possible to enhance the carabid beetle diversity and also the overall diversity with the integration of different crops in a crop rotation in order to provide different habitat conditions.

\subsection{Agroforestry System (Treatment 3)}

A complete list of all carabid beetle species collected from the agroforestry system at the experimental site Ihinger Hof is given in Table 8. The greatest proportion of carabid beetle individuals represented Pterostichus melanarius with $43.2 \%$ followed by Agonum muellerie (17.8\%) and Poecilus cupreus (15.8\%).

Table 8. Number of carabid beetle individuals collected at the agroforestry system at the experimental site Ihinger Hof, sampling period $4^{\text {th }}$ to $21^{\text {st }}$ June 2010 and their relative abundance (\%)

\begin{tabular}{llc}
\hline Species & Number of individuals $(n)$ & Frequency (\%) \\
\hline Pterostichus melanarius (ILLIGER) & 63 & 43.2 \\
Agonum muellerie (HERBST) & 26 & 17.8 \\
Poecilus cupreus (LINNÉ) & 23 & 15.8 \\
Pseudoophonus rufipes (DE GEER) & 18 & 12.3 \\
Amara aenea (DE GEER) & 7 & 4.8 \\
Bembidion testaceum (DUFTSCHMID) & 3 & 2.1 \\
Harpalus affinis (SCHRANK) & 2 & 1.4 \\
Carabus violaceus (LINNÉ) & 2 & 1.4 \\
Calathus cinctus (MOTSCHULSKY) & 1 & 0.7 \\
Ophonus ardosiacus (LUTSHNIK) & 1 & 0.7 \\
Total & 146 & \\
\hline
\end{tabular}

Table 9 reveals the calculation of the diversity indices Shannon-Wiener diversity $\left(H^{\prime}\right)$, Simpson diversity $(D)$ and Evenness $\left(J^{\prime}\right)$ for the whole agroforestry system. The diversity values $\left(H^{\prime}=1.562 ; D=0.739 ; J^{\prime}=0.678\right)$ indicated a medium balanced carabid beetle assemblage structure in this agroforestry system in comparison to the experimental sites discussed above.

Table 9. Activity density, species richness, Shannon diversity $\left(H^{\prime}\right)$, Simpson diversity $(D)$ and Evenness $\left(J^{\prime}\right)$ for the agroforestry system at the experimental site Ihinger Hof, sampling period $4^{\text {th }}$ to $21^{\text {st }}$ June 2010

\begin{tabular}{llllll}
\hline & Activity density & Species richness & $\begin{array}{l}\text { Shannon-Wiener } \\
\text { diversity }\left(H^{\prime}\right)\end{array}$ & $\begin{array}{l}\text { Simpson } \\
\text { diversity }(D)\end{array}$ & Evenness $\left(J^{\prime}\right)$ \\
\hline $\begin{array}{l}\text { Agroforestry } \\
\text { system }\end{array}$ & 146 & 10 & 1.562 & 0.739 & 0.678 \\
\hline
\end{tabular}


Figure 3 shows the results of the carabid beetle trapping in an agroforestry system in 2010 at the trial site Ihinger Hof regarding to the species richness. The agroforestry system consisted of 3 maize strips and different wood strips as explained in part 2.2. The grey strips in figure 5 represent the wood strips in the agroforestry system and the numbers Q1 - Q15 represent the transect with the pitfall traps arranged crosswise to the wood strips.

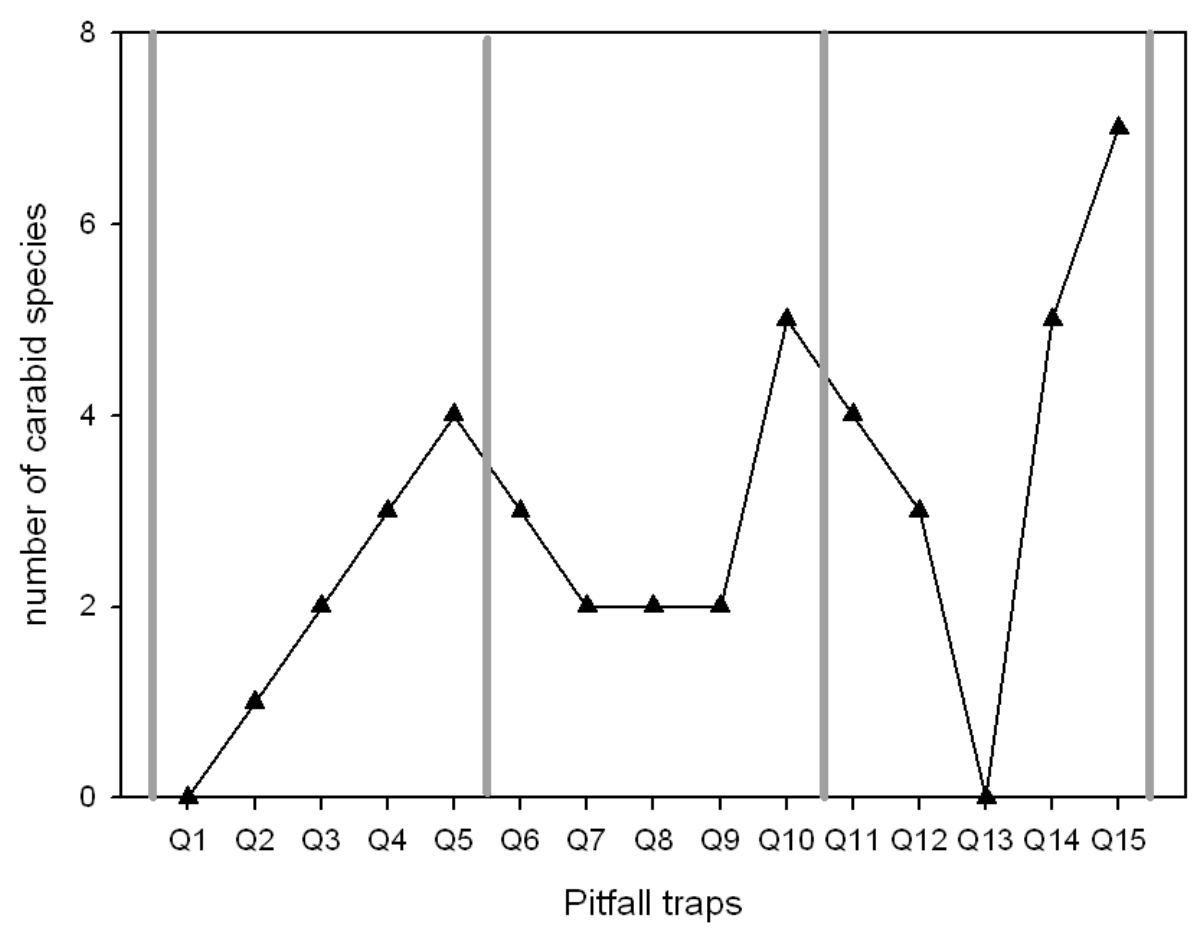

Figure 3. Carabid beetle species richness in the agroforestry system at the experimental site Ihinger Hof, sampling period $4^{\text {th }}$ to $21^{\text {st }}$ June 2010 . Grey strips $=$ wood strips of the agroforestry system, Q1-Q15 = number of pitfall traps. Distance between each pitfall trap was set to $16 \mathrm{~m}$.

A trend to higher carabid beetle species richness close to the wood strips was evident $(4-8$ carabid beetle species) except for the wood strip on the left side of the field, while the species richness in the middle of the 48 $\mathrm{m}$ maize strips decreased ( $0-2$ carabid beetle species) (Figure 5). This indicates that the wood strips may have similar effects on the carabid beetle diversity as a field margin, offering a potential refuge for several carabid species. All three kinds of wood strips were managed extensive and the strips with walnut and locally adapted hedge species were additionally under sown with grass. They provide landscape structural elements and refuge strips for carabid beetles as well as the overall field fauna regarding a habitat for overwintering and adverse agricultural activities within the field particularly in regions with a high monoculture density. A big advantage of this kind of strips compared to non-crop areas like field margins may be that the willow and the walnut strips have an additional economic benefit. The willow in this field experiment is used as a short rotation coppice; however other studies did not show direct positive effects on carabid species richness in short rotation coppice plantations (Allegro \& Sciaky, 2003; Schulz et al., 2009). Considering other animal species like different invertebrates (Liesebach et al., 1999) and birds (Liesebach et al., 1999; Sage et al., 2006; Fry \& Slater, 2011) positive effects of short rotation coppice are observed, especially if short rotation coppice are used in small plantations with a higher proportion of edge habitats (Christian et al., 1998) such as present in the mentioned agroforestry system with narrow elongated strips of willow. The results of the carabid sampling in the agroforestry systems indicates that such strip-wise cropping systems are able to provide improvements for intensive managed agricultural systems and in particular for bioenergy production systems.

\section{Conclusion}

Changes in agricultural land use as a result of an increased demand of energy crops have turned the focus of farmers on only a few important crops - in Germany particularly maize for biogas. To overcome the negative ecological and environmental side effects of biodiverse poor maize monocultures sustainable, biodiverse enriched alternative cropping systems are needed. The results of the different studies showed, that carabid 
diversity of cropping systems could be enhanced by the creation of refuge areas, which could be field margins with grass or hedgerows. Furthermore, other strip-wise cropping systems with perennial and annual crops are possible, whereas even the more extensively used perennial crop could provide a refuge for the field fauna as a habitat for overwintering or adverse agricultural activities. But it has to be assumed that certain adaption time is needed to establish a new balance in this agricultural ecosystem. The tested cropping systems of this study revealed different opportunities to enhance the carabid beetle species richness and probably the overall biodiversity of energy production systems. Results indicated that field margins have a great importance as a refuge for carabid beetles and may increase the carabid beetle diversity of adjacent agricultural used areas 3-4 fold. Furthermore, the field experiments indicated that artificially introduced refuge strips in the form of hedges, wood strips or extensively used perennial crops within a field may provide refuges for carabid beetles or other field fauna species. Field experiments with different annual crops like amaranth, sunflower, maize and clover grass showed no significant differences in carabid beetle species richness in the first experimental year. However, literature reveals that crop rotations consisting of different annual crops are able to enhance carabid beetle species richness and overall biodiversity of cropping systems compared to monoculture systems in the long term.

\section{Acknowledgements}

The research was carried out with funds of the Stiftung Energieforschung Baden-Württemberg, Karlsruhe. (FK A290 10), EnBW Energie Baden-Württemberg AG, Karlsruhe and Erdgas Südwest GmbH, Ettlingen.

\section{References}

Allegro, G., \& Sciaky, R. (2003). Assessing the potential role of ground beetles (Coleoptera, Carabidae) as bioindicators in poplar stands, with a newly proposed ecological index (FAI). Forest Ecology and Management, 175, 275-284. http://dx.doi.org/10.1016/S0378-1127(02)00135-4

Baguette, M., \& Hance, T. (1997). Carabid beetles and agricultural practices: influence of soil ploughing. Biological Agriculture and Horticulture, 15, 185-190. http://dx.doi.org/10.1080/01448765.1997.9755193

Benjamin, R., Cedric, G., \& Pablo, I. (2008). Modeling spatially explicit population dynamics of Pterostichus melanarius I11. (Coleoptera: Carabidae) in response to changes in composition and configuration of agricultural landscapes. Landscape and Urban Planning, 84, 191-199. http://dx.doi.org/10.1016/j.landurbplan.2007.07.008

Bundesministerium für Umwelt, Naturschutz und Reaktorsicherheit (BMU) \& Bundesministerium für Ernährung, Landwirtschaft und Verbraucherschutz (BMELV). (2010). Nationaler Biomasseaktionsplan für Deutschland - Beitrag der Biomasse für eine nachhaltige Energieversorgung. Berlin, Germany.

Carmona, D. M., \& Landis, D. A. (1999). Influence of refuge habitats and cover crops on seasonal activity-density of ground beetles (Coleoptera: Carabidae) in field crops. Environmental Entomology, 28, 1145-1153.

Christian, D. P., Hoffman, W., Hanowski, J. M., Niemi, G. J., \& Beyea, J. (1998). Birds and Mammals diversity on woody biomass plantations in North America. Biomass and Bioenergy, 14, 395-402. http://dx.doi.org/10.1016/S0961-9534(97)10076-9

Commission of the European Communities COM. (2005). Biomass Action plan. Brussels, Belgium.

Dritschilo, W., \& Erwin, T. L. (1982). Responses in abundance and diversity of cornfield carabid communities to differences in farm practises. Ecology, 63, 900-904. http://dx.doi.org/10.2307/1937229

Ellsbury, M. M., Powell, J. E., Forcella, F., Woodson, W. D., Clay, S. A., \& Riedell, W. E. (1998). Diversity and Dominant Species of ground beetle assemblages (Coloptera: Carabidae) in crop rotation and chemical input systems for the Northern Great Plains. Annals of Entomological Society of America, 91, 619-625.

Fachagentur für Nachwachsende Rohstoffe e.V. (FNR). (2012). Anbau nachwachsender Rohstoffe in Deutschland.

Fry, D. A., \& Slater, F. M. (2011). Early rotation short rotation willow coppice as a winter food resource for birds. Biomass and Bioenergy, 35, 2545-2553. http://dx.doi.org/10.1016/j.biombioe.2011.02.016

Golebiowska, H. (2011). Diversity of weed infestation depending on maize cropping system. Acta Scientiarum Polonorum, Agricultura, 10, 13-23.

Hatten, T. D., Bosque-Perez, N. A., Labonte, J. R., Guy, S. O., \& Eigenbrode, S. D. (2007). Effects of tillage on the activity density and biological diversity of carabid beetles in spring and winter crops. Environmental Entomology, 36, 356-368. http://dx.doi.org/10.1603/0046-225X(2007)36[356:EOTOTA]2.0.CO;2 
Holland, J., Fahrig, L. (2000). Effect of woody borders on insect density and diversity in crop fields: a landscape-scale analysis. Agriculture, Ecosystems and Environment, 78, 115-122. http://dx.doi.org/10.1016/S0167-8809(99)00123-1

Holland, J. M., \& Luff, M. L. (2000). The effects of agricultural practices on Carabidae in temperate agroecosystems. Integrated Pest Management Reviews, 5, 109-129. http://dx.doi.org/10.1023/A:1009619309424

Holland, J. M., Perry, J. N., \& Winter, L. (1999). The within-field spatial and temporal distribution of arthropods in winter wheat. Bulletin of Entomological Research, 89, 499-513. http://dx.doi.org/10.1017/S0007485399000656

Holland, J. M., Thomas, C. F. G., Birkett, T., Southway, S., \& Oaten, H. (2005). Farm-scale spatiotemporal dynamics of predatory beetles in arable crops. Journal of Applied Ecology, 42, http://dx.doi.org/10.1111/j.1365-2664.2005.01083.x

Horne, P. A. (2007). Carabids as potential indicators of sustainable farming systems. Australian Journal of Experimental Agriculture, 47, 455-459. http://dx.doi.org/10.1071/EA05265

Irmler, U. (2003). The spatial and temporal pattern of carabid beetles on arable fields in Northern Germany (Schleswig-Holstein) and their value as ecological indicators. Agriculture, Ecosystem and Environment, 98, 141-151. http://dx.doi.org/10.1016/S0167-8809(03)00076-8

Jeanneret, P., Schüpbach, B., Pfiffner, L., Herzog F., \& Walter, T. (2003). The Swiss agri-environmental programme and its effects on selected biodiversity indicators. Journal for Nature Conservation, 11, 213-220. http://dx.doi.org/10.1078/1617-1381-00049

Krebs, C. J. (2009). Ecology: The Experimental Analysis of Distribution and Abundance (sixth ed.). San Francisco, USA: Person.

Kromp, B. (1999). Carabid beetle in sustainable agriculture: a review on pest control efficacy, cultivation, impacts and enhancement. Agriculture, Ecosystem and Environment, 74, 187-228. http://dx.doi.org/10.1016/S0167-8809(99)00037-7

Kromp, B., \& Steinberger, K.-H. (1992). Grassy field margins and arthropod diversity: a case study on ground beetle and spiders in Eastern Austria (Coleoptera: Carabidae; Archnida: Aranei, Opiliones). Agriculture, Ecosystems and Environment, 40, 71-93. http://dx.doi.org/10.1016/0167-8809(92)90085-P,

Larsson, S. G. (1939). Entwicklungstypen und Entwicklungszeiten der dänischen Carabiden. Entomologiske Meddelelser, 20, 227-560.

Liesebach, M., Mulsow, H., Rose, A., \& Mecke, R. (1999). Ökologische Aspekte der Kurzumtriebswirtschaft (pp. 455-476), In: Schütte, A. (Ed.), Schriftenreihe Nachwachsende Rohstoffe 13- Modellvorhaben Schnellwachsende Baumarten. Münster, Germnay: Landwirtschaftsverlag GmbH.

Liu, Y., Axmacher, J. C., Wang, C., Li, L., \& Yu, Z. (2010). Ground beetles (Coleoptera: Carabidae) in the intensively cultivated agricultural landscape of Northern China - implications for biodiversity conservation. Insect Conservation and Diversity, 3, 34-43. http://dx.doi.org/10.1111/j.1752-4598.2009.00069.x

Magurran, A. E. (2004). Measuring Biological Diversity. Malden, USA: Blackwell Publishing.

Marshall, E. J. P., West, T. M., \& Kleijn, D. (2006). Impacts of agri-environmental field margin prescription on the flora and fauna of arable farmland in different landscapes. Agriculture, Ecosystems and Environment 113, 36-44. http://dx.doi.org/10.1016/j.agee.2005.08.036

O'Rourke, M. E., Liebman, M., \& Rice, M. E. (2008). Ground beetle (Coleoptera: Carabidae) assemblages in conventional and diversified crop rotation systems. Environmental Entomology, 37, 121-130. http://dx.doi.org/10.1603/0046-225X(2008)37[121:GBCCAI]2.0.CO;2

Pollard, K. A., \& Holland, J. M. (2006). Arthropods within the woody elements of hedgerows and their distribution pattern. Agricultural and Forest Entomology, 8, 203-211. http://dx.doi.org/10.1111/j.1461-9563.2006.00297.x

Sachverständigenrat für Umweltfragen (SRU). (2007). Klimaschutz durch Biomasse - Sondergutachten. Berlin, Germany: Erich Schmidt Verlag GmbH \& Co.

Sage, R., Cunningham, M., \& Boatman, N. (2006). Birds in willow short-rotation coppice compared to other arable crops in central England and a review of bird census data from energy crops in the UK. The 
$\begin{array}{llllll}\text { International Journal of Avian } & \text { Science } & \text { (IBIS), } & 148, & 184-197 .\end{array}$ http://dx.doi.org/10.1111/j.1474-919X.2006.00522.x

Saska, P., Vodde, M., Heijerman, T., Westermann, P., \& van der Werf, W. (2007). The significance of grassy field boundary for the spatial distribution of carabids within two cereal fields. Agriculture, Ecosystems and Environment, 122, 427-434. http://dx.doi.org/10.1016/j.agee.2007.02.013

Schulz, U., Brauner, O., \& Gruß, H. (2009). Animal diversity on short-rotation coppices - a review. Landbauforschung - vTI Agricultural and Forestry Research, 3(59), 171-182.

Sotherton, N. W. (1984). The distribution and abundance of predatory arthropods overwintering on farmland. Annals of Applied Biology, 105, 423-429. http://dx.doi.org/10.1111/j.1744-7348.1984.tb03068.x

Stoate, C., Boatman, N. D., Borralho, R. J., Rio Carvalho, C., de Snoo G. R., \& Eden, P. (2001). Ecological impacts of arable intensification in Europe. Journal of Environmental Management, 63, 337-365. http://dx.doi.org/10.1006/jema.2001.0473

Thiele, H.-U. (1977). Carabid beetle in their Environments. Berlin/ Heidelberg, Germany: Springer-Verlag.

Thomas, C. F. G., \& Marshall, E. J. P. (1999). Arthropods abundance and diversity in differently vegetated margins of arable fields. Agriculture, Ecosystems, and Environment, 72, 13-144. http://dx.doi.org/10.1016/S0167-8809(98)00169-8

Vetter, A., 2010. Standortangepasste Anbausysteme für Energiepflanzen. Gülzow, Germany: Fachagentur für Nachwachsende Rohstoffe e.V. (FNR).

Volkmar, C., \& Kreuter, T. (2006). Zur Biodiverität von Spinnen (Araneae) und Laufkäfern (Carabidae) auf sächsischen Ackerflächen. Mitteilungen der Deutschen Gesellschaft für allgemeine und angewandte Entomologie 15, 97-102.

Weidanz, J., \& Mosimann, T. (2008). Auswirkungen von Maisanbau zur Produktion von Biogas auf die Bodenerosion. Wasser und Abfall, 7-8, 16-20.

Willms, M., Glemnitz, M., \& Hufnagel, J. (2009). Entwicklung und Vergleich von optimierten Anbausystemen für die landwirtschaftliche Produktion von Energiepflanzen unter den verschiedenen Standortbedingungen Deutschlands (EVA), Schlussbericht zu Teilprojekt II: Ökologische Folgewirkungen des Energiepflanzenanbaus.

Yu, Z., Liu, Y., \& Axmacher, J. C. (2006). Field margins as rapidly evolving local diversity hotspots for ground beetles (Coleoptera: Carabidae) in Northern China. The Coleopterists Bulletin, 60, 135-143. http://dx.doi.org/10.1649/854.1 